\title{
SULFIDE MELT INCLUSIONS IN YUBILEINAYAN (YAKUTIA) DIAMONDS
}

\author{
Ofra Klein-BenDavid ${ }^{1}$, Alla M. Logvinova ${ }^{2}$, Elad S. Izraeli ${ }^{1}$, Nikolai. V. Sobolev ${ }^{2}$, Oded Navon $^{1}$ \\ ${ }^{1}$ Institute of Earth Sciences, The Hebrew University of Jerusalem, Israel; ${ }^{2}$ Institute of Mineralogy and Petrography, Siberian \\ Branch of Russian Academy of Sciences.
}

\section{INTRODUCTION}

Sulfide inclusions in diamonds provide unique information on the distribution of chalcophile elements in the mantle. Sulfide inclusions are common among the mineral inclusions in diamonds. The mineral assemblage includes Monosulfide solid solution (MSS), pyrite, pentlandite, pyrrhotite, and chalcopyrite. MSS are by far he most abundant. (Yefimova et al., 1983; Deines and Harris, 1995; Barashkov and Talnikova, 1996; Bulanova, 1995, Bulanova et al., 1996; Sobolev et al., 1997).

Sulfide minerals occur in both eclogitic and peridotitic paragenesis. Eeclogitic MSS contain 0-12\% Ni while peridotitic MSS contain 22-36\% (Yefimova et al., 1983; Bulanova et al., 1996).

Sulfide melts inclusions were never encountered before. Melts and other fluids were found in micro-inclusions in diamonds from Zaire, Botswana and South Africa (Navon et al., 1988; Schrauder and Navon, 1994; Izraeli et al., 2001). They carry carbonatitic melts, silicic melts and Cl-rich brine, but no sulfur.

Here, we present the first report of sulfide melt inclusions. The sulfide melts are found in diamonds from Yubileinaya (Yakutia) and in a few cases they coexist with carbonatitic melt inclusions.

Sulfide melts can shad a light on the evolution of mantle fluids from oxidized carbonatitc melts to more reduced sulfide melts, and on the transportation of chalcophile elements in the mantle.

\section{METHODS}

Four diamonds from the Yubilenaya mine, Yakutia, Siberia were analyzed. Diamonds UB-5 41 and UB-81 are fibrous cubes with a central cloud composed of millions of micrometer-size inclusions (Fig 1A). Diamond UB-3105 is an octahedral diamond with a central zone rich in larger inclusions (up to $\sim 100$ microns, see Fig 1B). Diamond UB-3158 is a dodecahedral diamond with a central zone rich in micro-inclusions. Diamond diameter is $0.15-2 \mathrm{~mm}(\sim 5$ mg each).

All diamonds were polished into $0.6-1 \mathrm{~mm}$ thick slabs with two parallel faces and cleaned with HF (60\%), $\mathrm{HNO}_{3}(69 \%)$ and ethanol prior to analysis, in order to remove all organic and inorganic contamination.
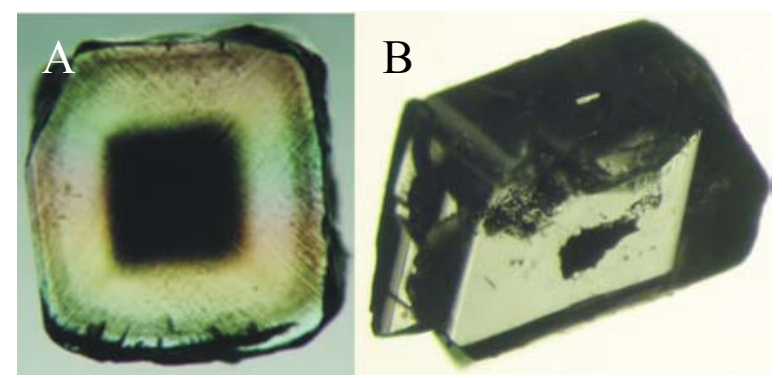

Figure 1: A. Diamond UB-5 41 . B. Diamond UB-3105

All diamonds were analyzed using FTIR with a Bruker IRscope II microscope coupled to a Nicolet 740 spectrometer for nitrogen concentration and aggregation-state. The net absorption of the inclusions was obtained by subtracting type II diamond spectrum and nitrogen absorption spectra (IaA or Iab) from the original spectra. The volatile content ratio $\left(\mathrm{CO}_{2} /\left(\mathrm{CO}_{2}+\mathrm{H}_{2} \mathrm{O}\right)\right)$ was calculated from the subtracted spectra.

Individual, shallow, subsurface inclusions were detected using back-scattered electron-imaging and analyzed for major-element composition using a focused $15 \mathrm{keV}, 10 \mathrm{nA}$ beam of JEOL JXA 8600 electron probe micro analyzer (EPMA) with a PioneerNorvar EDS detector and automation system.

Many of the inclusions occupied volumes that are smaller than the activated volume of analysis and yielded low totals. In UB-3158 the average total value is $53 \mathrm{wt} \%$, in UB-5_41 and UB-3158, it is lower: 8-9 wt $\%$ and in UB- 81 the average value is the lowest $\sim 4 \%$. The data were recalculated to $100 \%$. These differences may be the result of different inclusion size or different composition (e.g. the presence of oxides and carbonates, see below).

\section{RESULTS}

\section{FTIR SPECTRA}

The nitrogen aggregation state of diamonds UB-3158, UB-5 41 and UB-81 is $1 \mathrm{aA}$, their nitrogen content is $100, \overline{4} 65$ and $457 \mathrm{ppm}( \pm 10 \%)$ respectively. UB-3105 has a much lower $\mathrm{N}$ content $(30 \mathrm{ppm})$ the nitrogen aggregation state is $1 \mathrm{aA}$ but might with possible low percentage of $1 \mathrm{aB}$. 
No volatile species were observed in diamond UB-3105 spectrum, probably due to the large size of the inclusions and their opaque nature.

The two main volatile species measured in diamonds UB-3158, UB-5_41 and UB-81 are carbonate, with a band of $1449 \pm 9 \mathrm{~cm}^{-1}$ and water, with main peak is at $3420 \mathrm{~cm}^{-1}$. The concentration ratio $\left(\mathrm{CO}_{2} /\left(\mathrm{CO}_{2}+\mathrm{H}_{2} \mathrm{O}\right)\right)$ ranges between 0.26 and 0.65 .

Some peaks between $900-1100 \mathrm{~cm}^{-1}$ may represent silicate minerals, but no specific mineral could be identified.

\section{EPMA ANALYSES}

101 inclusions were detected in the fibrous zones and clouds of the diamonds and were analyzed by EPMA. They include silicate and oxide minerals, carbonatitic melts and $\mathrm{S}-\mathrm{Ni}-\mathrm{Fe}$ rich inclusions.

1. Peridotitic minerals were identified in two diamonds. In UB-3105 two inclusions carry $\mathrm{Si}, \mathrm{Mg}$ and $\mathrm{Fe}$ with $(\mathrm{Mg}+\mathrm{Fe}) / \mathrm{Si}$ ratio of 1.75 and $\mathrm{Mg \#}$ of 0.92 . These are probably olivine inclusions, but the reason for the low $(\mathrm{Mg}+\mathrm{Fe}) / \mathrm{Si}$ ratio is not clear. Two other inclusions carry chromite with $\mathrm{Cr} /(\mathrm{Cr}+\mathrm{Al})$ ratio of 0.87 . Olivinespinel thermometry (ONeill and Wall, 1987) yields temperature of $950 \pm 50^{\circ} \mathrm{C}$.

In UB-3158 four olivine inclusions have similar Mg\# and $(\mathrm{Mg}+\mathrm{Fe}) / \mathrm{Si}$ ratios. Six other inclusions have similar composition with average of $43.4 \pm 1.6 \mathrm{wt} \%$ $\mathrm{SiO}_{2}, \quad 12.9 \pm 0.7 \% \quad \mathrm{Al}_{2} \mathrm{O}_{3}, 4.2 \pm 0.4 \% \quad \mathrm{Cr}_{2} \mathrm{O}_{3}, 4.1 \pm 0.9 \%$ $\mathrm{FeO}, 22.4 \pm 0.6 \% \mathrm{MgO}$ and $10.4 \pm 0.6 \% \mathrm{~K}_{2} \mathrm{O}$. Their $(\mathrm{K}+\mathrm{Na}) / \mathrm{Si}$ ratio of 0.33 and $\mathrm{Al} / \mathrm{Si}$ ratio of 0.35 are similar to mica proportion and the high $\mathrm{Mg \#}$ $(0.91 \pm 0.02)$ suggest phlogopite, but we detected no Ti and elevated $\mathrm{Cr}$ content.

2. In UB-81 twenty-six micro-inclusions carry carbonatitic melts with average composition of $\mathrm{K}_{20} \mathrm{Na}_{14} \mathrm{Ca}_{15} \mathrm{Mg}_{28} \mathrm{Fe}_{5} \mathrm{Si}_{7} \mathrm{Al}_{0.5} \mathrm{Ti}_{0.8} \mathrm{Cl}_{6} \mathrm{P}_{2}\left(\mathrm{CO}_{3}\right)_{44}\left(\mathrm{H}_{2} \mathrm{O}\right)_{22}$ (mole proportions). The $\mathrm{CO}_{2} /\left(\mathrm{CO}_{2}+\mathrm{H}_{2} \mathrm{O}\right)$ ratio of this diamond is 0.65 .

Two inclusions of similar composition, $\mathrm{K}_{25} \mathrm{Na}_{19} \mathrm{Ca}_{13} \mathrm{Mg}_{12} \mathrm{Fe}_{6} \mathrm{Si}_{6} \mathrm{Al}_{1.4} \mathrm{Ti}_{0.9} \mathrm{Cl}_{10} \mathrm{P}_{4}\left(\mathrm{CO}_{3}\right)_{25}\left(\mathrm{H}_{2} \mathrm{O}\right)_{20}$, are present in diamond UB-5_41 along with sulfide inclusions. The $\mathrm{CO}_{2} /\left(\mathrm{CO}_{2}+\mathrm{H}_{2} \mathrm{O}\right)$ ratio of this diamond is 0.56 .

3. Three diamonds contain $\mathrm{S}-\mathrm{Ni}-\mathrm{Fe}$ rich inclusions. The inclusions in each diamond are similar in their $\mathrm{Ni} /(\mathrm{Ni}+\mathrm{Fe})$, but span a range of $\mathrm{S} /(\mathrm{S}+\mathrm{Ni}+\mathrm{Fe})$ ratios (Fig 2). Sixteen micro inclusions from UB-5 41 and nine from UB-3158 have similar $\mathrm{Ni} /(\mathrm{Ni}+\mathrm{Fe})$ of $0.63 \pm 0.07$ and their $\mathrm{S} /(\mathrm{S}+\mathrm{Ni}+\mathrm{Fe})$ ratios ranges between 0.35 and 0.61 . The $\mathrm{Ni} /(\mathrm{Ni}+\mathrm{Fe})$ ratio in 26 inclusions in diamond $\mathrm{UB}-3105$ is $0.33 \pm 0.02$ and the $\mathrm{S} /(\mathrm{S}+\mathrm{Ni}+\mathrm{Fe})$ ratio ranges between 0.46 and 0.64 .
Some sulfide inclusions in diamond UB-5 41, which trapped carbotatitic inclusions as well, carry up to 27 mole $\%$ of other elements, mostly alkalis and $\mathrm{Mg}$.

\section{DISCUSSION}

The sulfide inclusions span three arrays that are perpendicular to the compositional variation of the MSS mineral inclusions (Fig. 2). The $\mathrm{S} /(\mathrm{S}+\mathrm{Ni}+\mathrm{Fe})$ ratio spans a wide range, from values lower than the Hazelwoodite ratio (UB-5_41 and UB-3158) to ratios as high as that of pyrite (UB-3105).

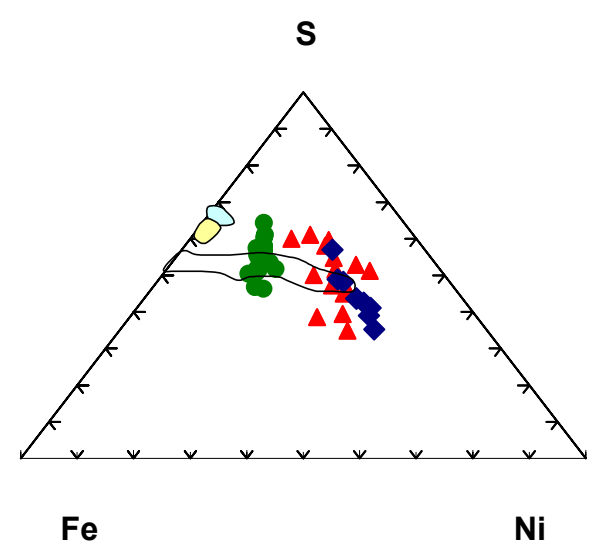

Figure 2: The sulfide inclusion composition in the Yubileinayan diamonds: UB-5_41 $\boldsymbol{\Delta}$, UB-3105 • and UB$3105 \bullet$. Also presented are sulfide inclusion compositional rang from other sources: MSS composition range $\square$, Chalcopyrite $\square$, Pyrite $\square$. (Deines and Harris, 1995; Spetsius et al., 2002 (in Zircon); Sobolev et al., 1997b; Barashkov and Talnikova, 1996).

The constant $\mathrm{Ni} /(\mathrm{Ni}+\mathrm{Fe})$ in the micro-inclusions precludes the explanation the observed $\mathrm{S} /(\mathrm{S}+\mathrm{Ni}+\mathrm{Fe})$ ranges by mixing a sulfide mineral with carbonatite melt. As the carbonatitic melts carry $\mathrm{Fe}$ but no $\mathrm{Ni}$, mixing would change the $\mathrm{Ni} /(\mathrm{Ni}+\mathrm{Fe})$ ratio.

The wide $\mathrm{S} /(\mathrm{S}+\mathrm{Ni}+\mathrm{Fe})$ range, the constant $\mathrm{Ni} /(\mathrm{Ni}+\mathrm{Fe})$, the presence of varying amounts of alkalis and $\mathrm{Mg}$ and the association with carbonatitic melts suggest that the sulfide-bearing micro-inclusions do not contain a mineral phase but rather, a sulfide melt. If true, this is the first finding of sulfide melts in diamond inclusions. The finding of similar sulfide melts in both octahedral and fibrous diamonds suggests that both habits can grow from the same fluid.

Finding sulfide melts along with carbonatitic melts imply that these two coexisted during the growth of the diamond. No mixed compositions were found in individual inclusions suggesting that the two melts did not mix. 
The Ni content in the sulfide melts in diamonds UB-

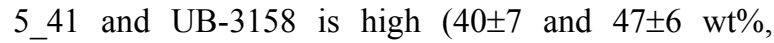
respectively), that of diamond UB-3105 is much lower, $21 \pm 2 \mathrm{wt} \%$. The high values fall above the range found in peridotitic MSS inclusions (15-36\%, Sobolev et al., 1997; Bulanova et al., 1996). The high Ni concentrations may reflect preferential partitioning of $\mathrm{Ni}$ into the melt. Using the partition coefficients of Barnes et al. (1997) the sulfide melts in all three diamonds coexisted with MSS containing 26-40 wt\% $\mathrm{Ni}\left(\right.$ at $1000^{\circ} \mathrm{C}$ ). This provides additional support to interpretation of these inclusions as sulfide melt inclusions.

The above observations draw a picture that is similar to that drawn by Bulanova et al. (1998). The four diamonds from Yubileinaya grew in an environment where sulfide melt coexisted with carbonatitic melt in a peridotitic rock (probably harzburgitic in view of the high $\mathrm{Cr}$ content of the phlogopites). Bulanova et al. (1998) studied inclusions and inclusion-rich zones in the centers of diamonds from Mir and Udachnaya. In central zones of peridotitic diamonds they found sulfides (mostly MSS), olivine, wustite, iron, graphite and carbonates. These zones were highly enriched in $\mathrm{K}, \mathrm{Ba}, \mathrm{Rb}, \mathrm{Sr}$, HFSE and $\mathrm{Cl}$. They interpreted these findings as reflecting a growth environment where carbonate and sulfide rich melts reacted with peridotitic minerals and a reducing iron-wustite-graphite assemblage.

Thus, the diamond probably grew in a peridotitic rock where both carbonatitic and sulfide melts were present. Although the sulfide melts also carry small amounts of alkalies and $\mathrm{Mg}$, we found no mixing between sulfide and carbonatitic melts. This may reflect immiscibility between the two melts (c.f. (Bulanova et al., 1998)).

The sulfide melts adds another branch to the system of diamond forming fluids encountered in diamonds. Carbonatitic melts are found together with hydroussilicic melts or with brine (Navon et al., this volume), now they are known to exist with and sulfide melts as well.

The sulfide melts can transport many chalcophile elements, including rhenium and osmium. Their occurrence here with carbonatitic melts raise the possibility that they may also be present in other diamond growth environments affect the trace elements, but avoid trapping.

\section{CONCLUSIONS}

Sulfide melts were found, for the first time, in diamond micro-inclusions. The melts span a wide range of $\mathrm{S} /(\mathrm{S}+\mathrm{Fe}+\mathrm{Ni})$ ratios but each diamond reveals a narrow $\mathrm{Ni} /(\mathrm{Ni}+\mathrm{Fe})$ range. $\mathrm{Ni}$ partitioning data suggests that even the high-Ni melts were in equilibrium with peridotitic MSS.

The sulfide melts were trapped in both octahedral and fibrous diamonds together with carbonatitic melts and peridotitic minerals. Water was also involved (IR spectrum and the presence of phlogopite). The common occurrence of sulfide and carbonatitic melts add another branch to the diamond forming fluids and widens the range of trace elements that may be transported by such fluids.

\section{REFERENCES}

Barashkov, Y.P. and Talnikova, S.B., 1996. Sulfide inclusions in diamonds and kimberlite minerals; similarities and differences (exemplified by the Udachnaya kimberlite pipe, Yakutia). Russian Geology and Geophysics, 37(6): 42-53.

Barnes, S.J., Makovicky, E., Makovicky, M., RoseHansen, J. and KarupMoller, S., $1997 . \quad$ Partition coefficients for $\mathrm{Ni}, \mathrm{Cu}, \mathrm{Pd}, \mathrm{Pt}, \mathrm{Rh}$, and $\mathrm{Ir}$ between monosulfide solid solution and sulfide liquid and the formation of compositionally zoned $\mathrm{Ni}-\mathrm{Cu}$ sulfide bodies by fractional crystallization of sulfide liquid. Canadian Journal of Earth Sciences, 34(4): 366-374.

Bulanova, G.P., 1995. The Formation of Diamond. Journal of Geochemical Exploration, 53(1-3): 1-23.

Bulanova, G.P., Griffin, W.L. and Ryan, C.G., 1998. Nucleation environment of diamonds from Yakutian kimberlites. Mineralogical Magazine, 62(3): 409-419.

Bulanova, G.P., Griffin, W.L., Ryan, C.G., Shestakova, O.Y. and Barnes, S.J., 1996. Trace elements in sulfide inclusions from Yakutian diamonds. Contributions to Mineralogy and Petrology, 124(2): 111-125.

Deines, P. and Harris, J.W., 1995. Sulfide Inclusion Chemistry and Carbon Isotopes of African Diamonds. Geochimica Et Cosmochimica Acta, 59(15): 3173-3188.

Izraeli, E.S., Harris, J.W. and Navon, O., 2001. Brine inclusions in diamonds: a new upper mantle fluid. Earth and Planetary Science Letters, 187(3-4): 323-332.

Navon, O., Hutcheon, I.D., Rossman, G.R. and Wasserburg, G.L., 1988. Mantle-drived fluids in diamond micro-inclusions. Nature, 335: 784-789.

Navon, O., Izraeli, E.S., and Klein BenDavid, O., 2003. Fluid Inclusions in Diamonds - The Carbonatitic Connection. Eight International Kimberlite Conference, long abstracts.

Oneill, H.S. and Wall, V.J., 1987. The Olivine OrthoPyroxene Spinel Oxygen Geobarometer, the Nickel Precipitation Curve, and the Oxygen Fugacity of the Earths Upper Mantle. Journal of Petrology, 28(6): 1169-1191.

Schrauder, M. and Navon, O., 1994. Hydrous and Carbonatitic Mantle Fluids in Fibrous Diamonds From Jwaneng, Botswana. 
Geochimica Et Cosmochimica Acta, 58(2): 761-771.

Sobolev, N.V. et al., 1997a. Mineral inclusions in diamonds from the Sputnik kimberlite pipe, Yakutia. Lithos, 39(3-4): 135-157.

Spetsius, Z.V., Belousova, E.A., Griffin, W.L., O'Reilly, S.Y. and Pearson, N.J., 2002. Archean sulfide inclusions in Paleozoic zircon megacrysts from the Mir kimberlite, Yakutia: implications for the dating of diamonds. Earth and Planetary Science Letters, 199(1-2): 111-126.

Yefimova, E.S., Sobolev, N.V. and Pospelova, L.N., 1983. Sulfide inclusions in diamonds and features of their parageneses. Zap. Vses. Mineral. Ova., 112(3): 300-310.
Contact: O Klein BenDavid, Institute of Earth Sciences, The Hebrew University of Jerusalem, Israel, 91904. E.mail: ofrak@vms.huji.ac.il 